\title{
Arquitectura moderna en el Campo de Gibraltar (1920-1970)
}

Durante los albores del siglo XX, el encuentro de la nueva objetividad con las vanguardias (constructivismo soviético, neoplasticismo holandés, Bauhaus) da lugar a un estilo nuevo, el movimiento moderno, al que los críticos consideran el más racional y auténtico desde el gótico. Sus tesis se van tejiendo a través de los congresos que lidera Le Corbusier: los CIAM. Su periodo canónico se establece entre 1920 y 1970, cincuenta años, como el Renacimiento. En España, el MoMo arraiga de forma distinta en sendos polos de la cultura arquitectónica: en Madrid es el grupo conocido como Generación del 25; en Barcelona, el GATCPAC. Pero lo interesante del caso español es que, pese a vicisitudes tan traumáticas como la guerra civil, la tensión creativa del MoMo se mantiene a lo largo de esos cincuenta años como estilo. Si bien el desenlace de la guerra supone no sólo la exclusión de un centenar de entre los arquitectos más comprometidamente modernos, sino también el apoyo circunstancial desde el nuevo Estado al eclecticismo historicista, lo cierto es que terminada la contienda mundial el gobierno español trata de agradar a los vencedores que identifican al moderno como el estilo propio de las democracias. El edificio de Sindicatos de Cabrero (1948) y el Gobierno Civil de Tarragona de Sota (1956) muestran un cambio de actitud que favorece la rápida recuperación de la modernidad. Especial interés presentan los pabellones españoles en las exposiciones internaciones que enlazan con la obra de Sert y Lacasa en la Expo de París del 37. Corrales y Molezún en Bruselas (1958) y Carvajal en Nueva York (1966) muestran al mundo que España apuesta por el MoMo.

Para analizar la influencia y alcance de la modernidad en el ámbito territorial del Campo de Gibraltar conviene hacer una breve sintesis de las circunstancias que van configurando la actual estructura urbana sobre la bahía de Algeciras. Este modelo se origina por la ocupación inglesa de Gibraltar en 1704; la población desplazada del peñón se asienta en otros lugares de la bahía, junto a la ermita de San Roque, en las ruinas de la antigua Algeciras y en torno al arroyo del Junco en Los Barrios. Los intentos de reconquista del peñón a lo largo de la segunda mitad del siglo XVIII propician un lento, pero constante proceso de población próximo a las fortificaciones de La Linea de la Contrabalación, hoy llamada "de la Concepción". El ámbito del actual área metropolitana se completa al norte con los municipios de Castellar y Jimena, y Tarifa al oeste, habitados desde la Edad Media.

Las actividades primarias con escasa productividad son los principales recursos de los habitantes de la comarca que circunda la colonia con una renta muy por debajo de la nacional, frente a la prosperidad que disfruta la nueva población gibraltareña al amparo del esplendor del imperio británico a partir del XIX. Esta burguesía a su vez desarrolla una serie de actividades productivas en el conjunto del territorio y como consecuencia de ello construye a principios del $X X$ algunos edificios de interés, entre los cuales destacan varios palacetes de estilo ecléctico histori- cista eduardiano y también posteriormente notables piezas modernas localizadas fundamentalmente en La Línea.

La celebración de la Conferencia de Algeciras en 1906 y la construcción del ferrocarril en 1892 por la sociedad The Algeciras-Gibraltar Railway \& Cía., cuyo accionariado mayoritario estaba compuesto por comerciantes gibraltareños e ingleses, supusieron un impulso definitivo en la expansión de Algeciras y sus instalaciones portuarias. La importancia que empieza a adquirir la ciudad se rubrica con la visita que realiza Alfonso XIII en 1909 y la creación un año después de la escuela de artes y oficios y el instituto nacional de enseñanza media, que vendría a convertir la ciudad en referencia en materia educativa de la comarca.

La radical transformación del sistema se produce a causa del cierre de la frontera con Gibraltar en 1969 y con la implantación del Plan de Desarrollo del Campo de Gibraltar de 1965, coincidente también con el inicio del desarrollo turístico de la comarca con urbanizaciones de alta calidad y grandes dimensiones.

El MoMo se va introduciendo en la comarca débilmente y a través de dos orígenes diferenciados: la vanguardia española (mercado de Algeciras) y la modernidad inglesa a través de Gilbraltar (chalet D'Amato). Las piezas más significativas las encontramos en Algeciras, Sotogrande (San Roque), La Línea de la Concepción y Gibraltar.

En Algeciras cabe destacar el mercado de abastos (1933 y 1935) de Torroja y Sánchez Arcas, el instituto de enseñanza secundaria Kursal (1935) de Trinidad Salesio, ambos protegidos como BIC. Y el parque de bomberos (años 50) de Manuel Blanquez (sobre un edificio preexistente), actualmente sometido a un proceso de rehabilitación y transformación.

En San Roque, dentro de la urbanización Sotogrande, se encuentran la casa Club de Golf (1963) de Luis Gutiérrez Soto, reformado y ampliado por Riveiro Pita, el hotel Sotogrande (1965) de José Antonio Corrales, posteriormente transformado, la casa Zobel (1970) de José Antonio Coderch, y la Casa Biddle (1966) de Javier Carvajal.

La Linea de la Concepción disponía de un notable conjunto de edificios, poco conocidos, de los que un buen número han desaparecido, entre los que cabe citar los chalets Villa Laura y Villa Luisa, ambos sitos en la avenida de España, y un bloque de viviendas en el paseo de la Velada, todos ellos construidos en los años 30. Entre los que aún permanecen, las piezas más significativas son el cine Imperial (1940) y el instituto de enseñanza media (1940), ambos actualmente fuera de uso, de Sánchez Esteve y el antiguo hotel Universal (1939), obra del ingeniero militar Facio Gómez. Quizás la pieza más sobresaliente sea el chalet D'Amato en la calle Clavel por su pureza de lineas; ha sido adaptado al uso docente para sede de

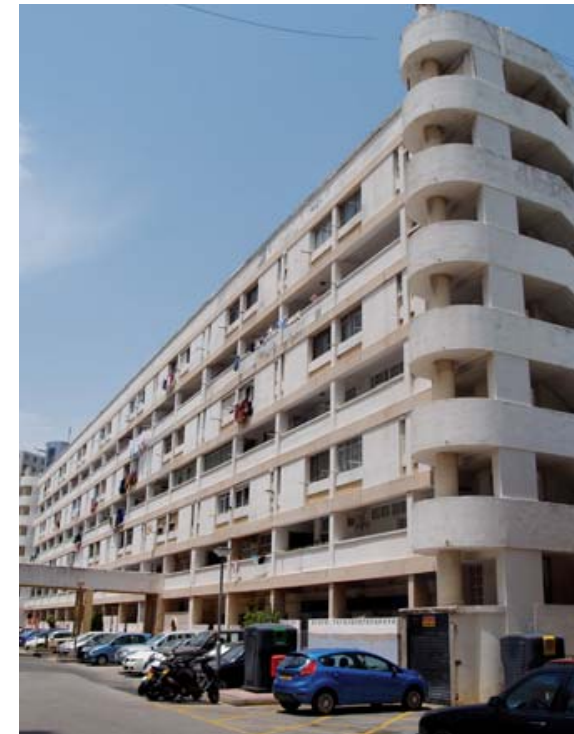

Imagen actual Referendum House Foto: Luis Modet Vaughan

la Universidad Internacional Menéndez Pelayo respetando su apariencia exterior, sólo alterada por la ubicación de un ascensor, realizando una profunda transformación de su distribución interior.

En la próspera ciudad de Gibraltar, el MoMo se implanta siguiendo la dinámica de la metrópoli. De hecho, en el Reino Unido el peso de la tradición historicista retrasa la modernidad, más presente en la arquitectura industrial que en la doméstica. Es después de la guerra mundial cuando los arquitectos ingleses se suman a la vanguardia europea a través del MARS, sección británica de los CIAM, e incluso protagonizan su décimo congreso que se celebra en Dubrovnik en 1956 y da lugar al nacimiento del Team Ten liderado por Alison y Peter Smithson. Así pues en la ciudad antigua gibraltareña aparecen durante los años 40 y 50 una serie de edificios tardo racionalistas de entre los cuales destacan el edificio Gordon en Cooperage Lane 9, el City Fire Brigade Station, el de Seccone \& Speed en Devils Tower Road, el edificio frente a la jefatura de policia en Line Wall Road y el adyacente a la oficina del Gib Heritage Trust. Pero sin duda la arquitectura moderna más relevante es el conjunto de viviendas sociales Referendum House (1965-1969), obra del arquitecto gibraltareño Sanguinetti, inspirado en las propuestas del Team Ten, en especial por la Robin Hood Gardens de los Smithson, a su vez heredera de los redents ideados por Le Corbusier para su Ville Radieuse, que en España se materializan en la casa Bloc (1933) de Sert, Subirana y Torres Clavé.

Luis Modet Vaughan, Julio Malo de Molina y Martín Montalvo, arquitectos 